\title{
Want to Study the Nature of Power? Start by Moving the Chairs!
}

Meg Mott, Marlboro College

ABSTRACT At first glance, the political-theory classroom can seem like a "philosophy class in disguise." How can we make our text-based classes more "political"? This article considers how three teaching formats-debate, fishbowl, and forum theater-enact different types of power in the classroom and how those enactments necessitate political judgments. In addition to creating the need for political analysis, each of these formats embodies a particular rhetorical strategy often used by political theorists. By physicalizing the argumentative, introspective, and descriptive devices that writers of political theory use, students become better readers of these often old and usually dense texts.

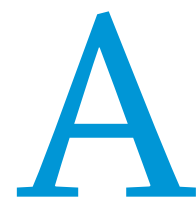

$\mathrm{t}$ its core, political science is the study of power. How we study power, however, depends largely on our subfield. Most subfields rely on empirical evidence to support their claims; however, in political theory, the evidence can seem insubstantial, as if it were conjured up out of thin air. What are we talking about when we expound on power? What does it have to do with texts written hundreds of years ago? With its impressive canon, political theory can seem like a "philosophy class in disguise," not a robust investigation of political actors (Staudinger 2014). Getting these ancient, modern, and postmodern thinkers to speak to twentyfirst-century concerns can be quite challenging. What do these often old and usually dense formulations about social and political power have to say to our students?

For the past three years, I have been balancing text-based discussions with weekly "activities," using one of three formats: debate, fishbowl, and forum theater. Initially, I was drawn to these teaching techniques to break up what my colleague calls "the long march of classes" since there is nothing like moving furniture to infuse new energy in the classroom. Because each technique grants students the power to stage and critique classroom confrontations, I had anticipated that all three would de-center my authority. What I had not anticipated was that as my authority declined, the authority of the texts reemerged. Theory does not only provide the content of a debate (e.g., a policy debate between a libertarian and a communitarian); it also provides the rubric to assess the political benefits of the conflict. For example, determining whether a debate was advantageous to the well-being of the classroom requires knowing something about a collective's well-being.

The second unanticipated outcome was that each format foregrounds a distinct rhetorical strategy. Debate teaches the

Meg Mott teaches politics at Marlboro College in Marlboro, Vermont. She can be reached atmegmott@marlboro.edu. importance of a solid counterargument; a fishbowl promotes exegetical inquiry; and forum theater demonstrates the importance of providing compelling examples when arguing for solutions. By moving the chairs in the political-theory classroom, not only is fresh energy brought into the space; students also develop skills as readers and writers of political theory. Having participated in a debate, a writer understands why a straw man does not advance one's position. Having sat down in a fishbowl, a writer discovers the value of multiple interpretations. Having intervened in a forum-theater improvisation, a writer recognizes the importance of sensory details to provoke political action.

\section{DEBATE}

Debate has an established place in both political-theory and political-science classrooms. A comparative study of student outcomes in two introductory political-science classes-one lecturebased and one debate-based-found that debates are "more effective in developing students' comprehension of complex concepts and application and critical evaluation skills" (Omelicheva and Avdeyeva 2008, 606). In addition to improving comprehension through application, debate teaches how to confront an opposing position without destroying it. As in written arguments, debate cultivates a "willingness to address opposing viewpoints," a "readiness to abandon apparently adamantine positions," and a capacity "to negotiate multiple truths" (Cioffi 2005, 103).

The idea that disagreement improves discussion may seem counterintuitive to a generation of American college students raised to be conflict averse. They want safety and support, not confrontation. They value tolerance over negotiating substantive differences. Students who are reading Machiavelli, however, come to understand the benefits of a "good clash." "[E]nmities between the senate and the plebeians" were useful, he counseled, when "they gave rise to laws in favor of liberty" (Machiavelli 1997/1531, 101). Class, religious, gender, racial and 
other identity-based antagonisms do not necessarily hurt the health of the republic. Done well they reign in the absolute power of the ruling regime.

By watching debates, judges learn to discern between productive disagreements and power plays. When does the clash improve the overall argument and when does it silence one side? Without political theory, debate can deteriorate to mere technical prowess, as evidenced in the fast-paced, point-based practice of forensics, in which the aim is to win by destroying the points raised by one's opponent (Rozinski 2014). With political theory, the democratic effectiveness of the debate can be assessed. Rather than avoid confrontation with their peers, debate teaches students how "the public competition of private arguments" can serve "the interest of all" (Habermas 1999, 83).

\section{FISHBOWL}

Not all students are comfortable participating in a debate. Quieter students and those new to political theory are reluctant to push their views against others. In an effort to develop critical skills in a safer environment, multicultural educators devised the practice of "fishbowls." In this process-oriented format, students learn what constitutes a "good discussion" (Facing History and Ourselves 2014). By focusing on the interactions among different types of students, the class becomes more aware of how social hierarchies (e.g., patriarchy and white supremacy) reproduce themselves. Like debate, a fishbowl allows for improvement through observation; students on the outside of the fishbowl listen and pay attention to the discussion occurring inside it.
Students who always speak learn to be more thoughtful about how much time they use to make their points and what tone of voice they employ. Students who never speak in class enter the fishbowl knowing they will not be judged for their uncertainty. Fishbowls subvert the norms of a discussion-based classroom by privileging relationships over assertions.

That said, fishbowls themselves are not above criticism. The emphasis on creating "a good discussion" instead of "a good clash" might be interpreted as a technique of governance. Students who are reading Michel Foucault may wonder whether the fishbowl incites "confessions" through the exercise of pastoral power (Foucault 1990, 61-2). Students who are reading bell hooks could rightly question what self-serving biases are being protected under the banner of safety and support (hooks 2015, 64). And while students who are reading Nancy Fraser will recognize the benefits of "subaltern counterpublics"-that is, spaces in which excluded voices are allowed to generate new arguments, they are also aware of the dangers of echo chambers (Fraser 2014, 82). Arguments formed in subaltern counterpublics, argues Fraser, will "have to be publicly argued out" to avoid their antidemocratic tendencies (Fraser 2014, 82).

A fishbowl also is useful in developing exegetical skills. In this application, the prompt for the discussion is a passage from the text written on the board. The first three students begin to explore what those words might mean, with observers entering the discussion to offer new interpretations. The fishbowl, like exegesis, encourages "the dramatic use of language," a term used by literary critics to underscore the way that words and sentences

\section{Whereas a debate fosters strong opposition and linear development, a fishbowl fosters peripheral alliances and lateral surprises.}

A fishbowl typically starts with an open-ended and relevant question, such as "How would your education be enhanced by a more diverse classroom?" In the center of the classroom are four chairs, one of which must always remain empty. Three students take their places in the inner circle and begin the discussion. The other students watch from an outer circle. When observers believe that a perspective is not being adequately addressed, they approach the empty chair. Before they can sit down, one of the original speakers must get up. The "One Chair Must Be Empty Rule" disrupts any possibility of one voice dominating the discussion. The constant stream of participants ensures that no one person or position can control the terms of the conversation.

Skilled debaters are often lost in a fishbowl. First, everyone is observing whether they are opening up the discussion by making room for others. Second, there is no opponent with whom to clash. Rather than strongly assert their points, participants in a fishbowl tone down their authority and speak from experience. Whereas a debate fosters strong opposition and linear development, a fishbowl fosters peripheral alliances and lateral surprises. Students who might have taken an adversarial tone in a debate find themselves having to tolerate a new point of view lest they be judged as too aggressive.

In a classroom in which a few students dominate the discussions, a fishbowl makes those undemocratic habits apparent. Post-fishbowl analysis calls for normative theory as the class begins to identify the elements of a productive conversation. talk to each other (Poirier 1977, 452). Words have a way, Richard Poirier wrote, of undoing and reconstituting each other "beyond the grasp of critical interpretations that look for unity and order" (Poirier 1977, 452). Freed of commitments, open to possibilities, and sensitive to the powerful effects of words, a fishbowl can generate new ideas and new interpretations that then can be tested in the crucible of debate.

\section{FORUM THEATER}

Created by Brazilian legislator and theater director Augusto Boal, forum theater uses theater techniques to raise awareness about the conditions of oppression (Boal 1993). A space is created at the front of the room where actors play out an oppressive scene in front of an audience of "spect-actors." When the scene reaches an unbearable situation, members of the audience jump in and perform what they wish to see happen. The process continues as new spect-actors intervene in the revised scene. Afterwards, the group as a whole analyzes the various iterations of the scene and how they might create more effective interventions.

Forum theater may seem more appropriate for resident-life training, where it is used in bystander intervention programs and anti-racism workshops, than for the political theory classroom. The work is practical and fast: "Here is a bad scenario. Here is where we get stuck. What can we do to turn this situation around?" There are no arguments to posit and no counterarguments to be accommodated or dismissed, debate-style. 
Neither does forum theater cultivate the type of intellectual curiosity that happens in a fishbowl. Forum theater can seem "too hot" for a academic classroom. Where does the analysis come in?

The political philosophy behind Boal's "theater of the oppressed" presumes that (1) only the oppressed can change the conditions of oppression; and (2) the power to change comes through performing that change (Boal 1993). Understanding power through its felt experience is a key lesson of forum theater. Power is merely an abstraction if it is not felt. The practice of forum theater is in line with Marx's optimism that the proletariat eventually will come to "feel its strength" through the very conditions that oppress them (Marx 2011/1848, 74). Social power as a concept can feel very abstract. Social power after a successful intervention suddenly feels real.

As in debate, the success of forum theater depends on the validity of the clash. The reenactment works only if the antagonisms feel real. Unlike debate, there is no presumption of equality at the outset. Rather, forum theater assumes that some of the actors are in more difficult circumstances than others. It is not enough to simply provide the two "sides" with equal allotments of how the rhetoric of uncertainty can challenge dominant frameworks (Foucault 1972, "Introduction").

Students familiar with forum theater will recognize those rich descriptions that compel an intervention, such as Marx's detailed picture of the London journeyman baker during the early phases of industrialization (Marx 1978/1867, 368-370) or Audre Lorde's physical description of fear (Lorde 2007). Real world examples crafted with visceral language move the reader in ways that abstract reasoning cannot. When students do not find this rhetorical strategy in the text, however, there is nothing to stop them from using their training and performing their own rhetorical intervention. Readers who know what to look for are compelled to be better writers.

By creating a space for clash, conversation, and embodied conflict, all three formats make visible the political phenomena that political theorists interrogate. When we only discuss the political phenomena, students are rightly confused about whether they are in a philosophy class. However, when we enact the stuff of political life-articulating difference, exploring alternative perspectives, and intervening in unjust situations-the real effect

When we only discuss the political phenomena, students are rightly confused about whether they are in a philosophy class. However, when we enact the stuff of political life-articulating difference, exploring alternative perspectives, and intervening in unjust conditions - the real work of political theory becomes apparent.

speaking time; the oppressive circumstances must be changed. In forum theater, "winning" requires that everyone becomes more conscious of the nature of structural oppression and more inspired to collaborate with others to change that state of affairs. But forum theater does not just depend on critical theory; it also requires normative theory. As with the other two formats, the observers are compelled to ask the sort of questions that normative theory is designed to answer:, "What constitutes a successful intervention? Which strategy actually increased the social power of the community?

\section{THE RHETORICAL STRATEGIES OF POLITICAL THEORISTS}

All three formats make visible what political theorists do rhetorically on the page. By regularly performing these formats, students are better able to recognize persuasive strategies in the reading. Debate teaches the skills of argument, of pressing one's claims against a respected opponent. Debaters recognize when a counterargument appears and when the author is engaged in rebuttal. Knowing the sequence of debate makes it easier to understand what political theorists are doing when they conjure up interlocutors, anticipate opposing arguments, and then lay them to rest.

Students familiar with the fishbowl will recognize moments in the text when the author stops pushing a thesis and starts opening up other possible interpretations. This quieter, more introspective register is often found in essays, a genre whose political significance is often overlooked. Attuned to this more introspective register, students familiar with the fishbowl will recognize elements of political theory in the essays of Michel de Montaigne, Audre Lorde and Virginia Woolf. Foucault's introduction to The Archaeology of Knowledge is another example of of political theory becomes apparent. These structured activities are never meant to displace the texts, but to make it more delightful (and necessary) to handle them.

\section{ACKNOWLEDGMENT}

I thank Khristina Haddad, Alison Mott, Etan Nasruddin-Longo, Jacob Turino, the participants in the "Teaching Political Theories" Track of APSA's 2014 Teaching and Learning Conference as well as the anonymous reviewers at PS: Political Science and Politics for their insightful comments and criticisms.

\section{REFERENCES}

Boal, Augusto. 1993. Theater of the Oppressed, trans. Charles A. McBride, et al. New York: Theater Communications Group

Cioffi, Frank. 2005. The Imaginative Argument. Princeton, NJ: Princeton University Press.

Facing History and Ourselves. 2014. "Teaching Strategy: Fishbowl." Available at https://www.facinghistory.org/for-educators/educator-resources/teachingstrategies/fishbowl.

Foucault, Michel. 1972. The Archaeology of Knowledge. New York: Routledge Press.

. 1990. History of Sexuality, Vol. 1, trans. Robert Hurley. New York: Vintage Press.

Fraser, Nancy. 2014. Justice Interruptus: Critical Reflections on the "Postsocialist" Condition. New York: Routledge Press.

Habermas, Jürgen. 1999. The Structural Transformation of the Public Sphere, trans. Thomas Burger. Cambridge, MA: MIT Press.

hooks, bell. 2015. Feminist Theory: From Margin to Center. New York: Routledge Press.

Lorde, Audre. 2007. Sister Outsider: Essays and Speeches. New York: Ten Speed Press.

Machiavelli, Niccolo. 1997/1531. Discourses on Livy, trans. Julia Conway Bondanella and Peter Bondanella. New York: Oxford University Press.

Marx, Karl. 2011/1848. The Communist Manifesto. New York: Penguin Classics. 
1978/1867. Capital Volume 1 in The Marx-Engels Reader, ed. Robert C. Tucker. New York: W.W. Norton \& Co.

Omelicheva, Mariya Y., and Olga Avdeyeva. 2008. "Teaching with Lecture or Debate? Testing the Effectiveness of Traditional versus Active Learning

Methods of Instruction." PS: Political Science and Politics 41 (3): 603-7.

Poirier, Richard. 1977. "Reading Pragmatically.” In Pragmatism: A Reader, ed. Louis Menand, 436-55. New York: Vintage Press.
Rozinski, Thomas. 2014. "Incorporating Debate into the Teaching of Political Theory." Paper presented at the 2014 APSA Teaching and Learning Conference, Philadelphia, February 7-9.

Staudinger, Alison. 2014. "To the Mind What Exercise Is to the Body? Identifying, Promoting and Measuring Close Reading Habits." Paper presented at the 2014 APSA Teaching and Learning Conference, Philadelphia, February 7-9. 